\title{
Partial Discharge under Pulse Voltage with Narrow Pulse Width
}

\author{
Koji Obata Member (Hitachi, Ltd., koji.obata.dy@ hitachi.com) \\ Ryozo Takeuchi Member (Hitachi, Ltd., ryozo.takeuchi.wk@hitachi.com) \\ Tadahiro Shimozono Non-member (Hitachi Industrial Equipment Systems Co. Ltd., \\ shimozono-tadahiro@hitachi-ies.co.jp)
}

Hideyuki Kikuchi Non-member (Hitachi Magnet Wire corp., kikuchi.hideyuki@hmw.hitachi-cable.co.jp)

Keywords : inverter, surge, pulse width, insulation, partial discharge, lifetime

The number of adjustable speed drives with voltage inverters has increased because of benefits for high energy efficiency, energy-savings and flexible controls. But various problems have been reported regarding with steep-fronted and high repetitive surge voltages generated by inverters. For example increase of the voltage stress at the motor terminal and increase of the voltage distirbution between windings are caused by the steep fronted surge voltages of inverters and these stresses are repeated by high carrier frequency of the inverter. In addition, voltage waveforms of turn-to-turn insulations are quite different from those in conventional motors, so voltage agings of insulations may also be different from those in conventional motors. In this paper, partial discharge (PD) characteristics under pulse voltages with narrow pulse width which are usually seen at turn-to-turn insulations in motors fed by inverter drives are described.

Partial discharge inception voltage (PDIV) under pulse voltages with narrow pulse width is shown in Fig. 1. PDIV increases with decreasing pulse width of apply voltage compared with PDIV of sine voltage. But the increase of PDIV is little for high repetition frequency.

The number of PD under pulse voltages with narrow pulse width is shown in Fig. 2. The number of PD decreases with decreasing pulse width of apply voltage.

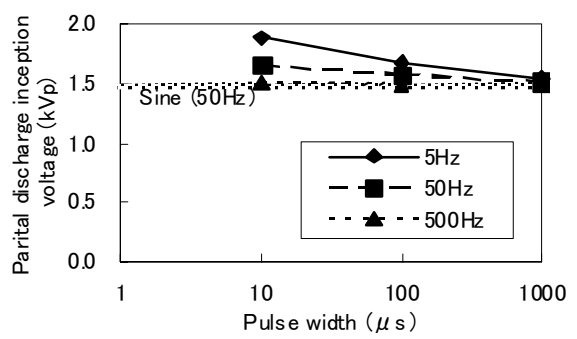

Fig. 1. Partial discharge inception voltage changing width and frequency of pulse voltage compared with sine voltage (sample: polyimide)

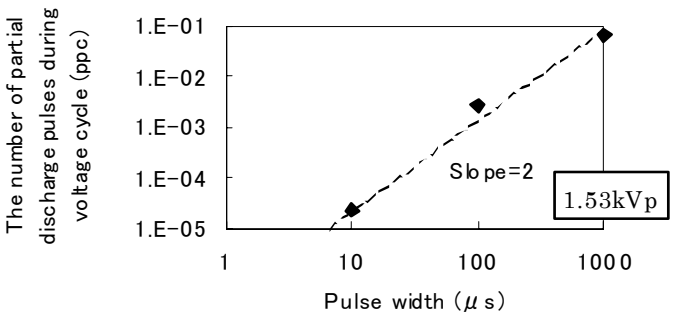

Fig. 2. The number of partial discharge changing pulse width of voltage around partial discharge inception voltage of sine (sample: polyimide, frequency: $50 \mathrm{~Hz}$ )
Lifetime characteristics under pulse voltage is shown in Fig. 3. Time-to-failure of enameld wire applied with pulse voltage increases with decreasing pulse width. In addition, voltage at which lifetime curve becomes horizontal and the lifetime seems to be infinite is higher than that of pulse voltage with wide pulse width.

Waveforms of turn-toturn voltage of a motor applied surge voltage is shown in Fig. 4. A steep-fronted surge voltage transmits in the winding from line side coil "U1" to neutral side coil "U4". As a result, turn-to-turn voltages occur at each coil. The width of turn-to-turn voltage is less than $1 \mu \mathrm{s}$. This is nealy equal to or less than the width of pulse voltage which influences PD and lifetime characteristics. So, it is found that we should measure the waveform of turn-toturn voltage and consider the electrical agings under such a pulse voltage with narrow pulse width.

One of the reason why these phenomina occur is thought as time lag of spark, especially statistical time lag. Although all results are not shown in this summary, the increase of PDIV decreased when UV is irradiated. The increase of PDIV decreased with increasing the repetition frequency of pulse voltage. These factors influence the population of initial electron and the probability that initial electron is accelarated during a certain interval. So, it is thought that these phenomina described in this paper are ocurred by statistical time lag of spark.

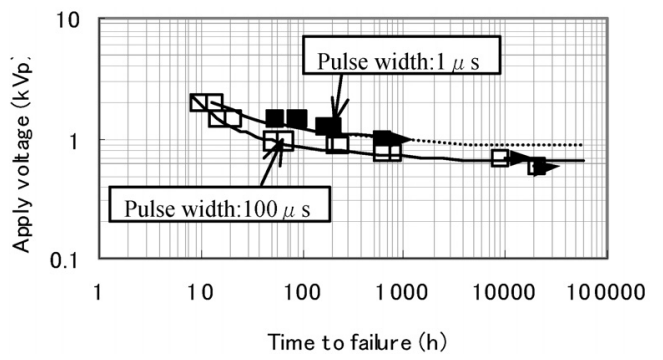

Fig. 3. Lifetime characteristics changing pulse width (sample: polyester-imide/polyamide-imide, frequency: $500 \mathrm{~Hz}$ )

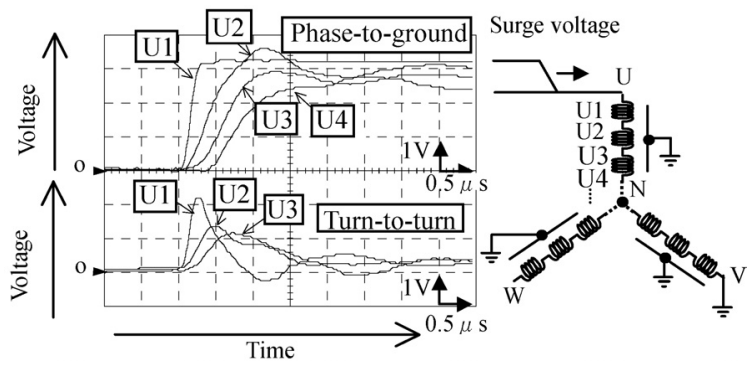

Fig. 4. Turn-to-turn voltage of motor applied surge voltage 


\title{
幅の狭いパルス電圧下の部分放電特性
}

\author{
正 員 尾畑 功治* 正 員 武内 良三* \\ 非会員 下䄇 忠弘 $* *$ 非会員 菊池 英行 $* * *$
}

\author{
Partial Discharge under Pulse Voltage with Narrow Pulse Width \\ Koji Obata*, Member, Ryozo Takeuchi*, Member, Tadahiro Shimozono**, Non-member, \\ Hideyuki Kikuchi***, Non-member
}

When steep-fronted surge voltages are generated and applied to a motor by an inverter drive, higher voltages are distributed at turn-to-turn insulations than those of a motor supplied by line voltage. In addition, the voltage waveforms are quite different, especially pulse widths of them are narrower than those of a motor supplied by line voltage. This paper describes partial discharge and electrical lifetime characteristics of turn-to-turn insulation when pulse voltages are applied. As a result, it is found that partial discharge inception voltage increases, the number of partial discharges decreases and lifetime of insulations increases when pulse widths of applied voltages decrease as narrow as those of turn-to-turn voltages of motors fed by inverter drives. These results can probably improve a present design and a quality assurance of materials and motor insulations for inverter drives in the future.

キーワード : インバータ, サージ, パルス幅, 絶縁, 部分放電, 寿命

Keywords : inverter, surge, pulse width, insulation, partial discharge, lifetime

\section{1. はじめに}

近年，産業用，自動車，鉄道などではインバータを用い たモータの可変速，省エネルギー運転が盛んに行われてい る。また，パワー半導体，ドライブ制御技術の発展ととも に, 今後もモータのインバータ駆動化は拡大寸ると考えら れる。しかし，インバータ駆動に伴いモータでは新たな問 題が報告されつつある(1)。例えば，急峻なインバータサージ 電圧がモータに印加されると, 正弦波駆動時と異なりモー タの巻線間に幅の狭い両極性スパイク状の高電圧パルスが 発生することが報告されている(2) (5)。本研究では今回新た にこのような幅の狭い両極性スパイク状の高電圧パルスに 対する絶縁物の部分放電特性および課電寿命特性を測定, 検討した。

\section{2. 実験方法}

〈2·1〉試験試料＼cjkstart表 1 および図 1 に試験に用いた絶 縁材料およびモデルを示す。試験には, モー夕巻線に一般 的に使用される 5 種類の絶縁材料を使用した。また, 各材 料を使用してモータ巻線間絶縁部を模擬したモデル試料を 作成した。マイカ, ポリイミド, 二重ガラス被覆, エナメ ル十二重ガラスでは, 絶縁被覆電線の導体平坦部をつき合 わせた背合わせ電線試料を作成した。絶縁被覆電線の絶縁

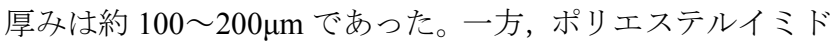
/ポリアミドイミドエナメルでは, 2 本のエナメル電線を撚 り合わせたツイストペア電線試料を作成した。電線の線径 は $1.0 \mathrm{~mm}$ であり，絶縁被覆厚みは約 $30 \mu \mathrm{m}$ であった。

$\langle 2 \cdot 2\rangle$ 試験回路図 2 に部分放電計測回路を示寸。今

Table 1. Test materials for turn-to-turn insulation of motor.

\begin{tabular}{|l|l|l|}
\hline & \multicolumn{1}{|c|}{ Insulator } & \multirow{2}{*}{ Model } \\
\hline 1 & Mica & \multirow{2}{*}{ Fig. 1 (a) } \\
\hline 2 & Polyimide & \\
\hline 3 & Double Glass Coat (DGC) & \\
\hline 4 & Enamel+DGC & \multirow{2}{*}{ Fig. 1 (b) } \\
\hline 5 & Polyester-imide/Polyamide-imide &
\end{tabular}




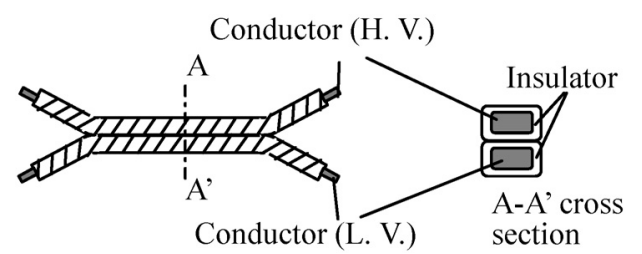

(a) Arrow pair model

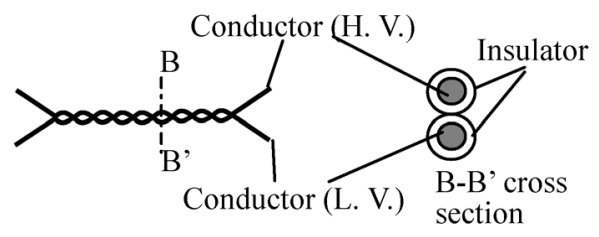

(b) Twisted-pair model

図 1 モータ巻線閒絶縁試験モデル

Fig. 1. Test models for turn-to-turn insulation of motor.

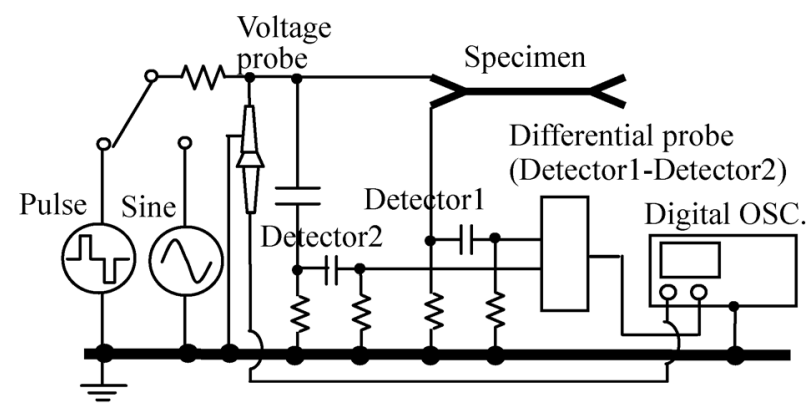

図 2 パルス／正弦波部分放電測回路

Fig. 2. Electrical circuit for measuring partial discharge characteristics under pulse/sine voltage.

回, パルス電源と正弦波 $50 \mathrm{~Hz}$ 電源を使用し，電圧立ち上が り時間が部分放電特性に及ぼす影響を検討した。図 3 にパ ルス電圧波形の例を示す。パルス電圧の立ち上がり時間, 立ち下がり時間はそれぞれ約 $1 \mu \mathrm{s}$, 約 $30 \mu \mathrm{s}$ であった。一方， パルス電源ではさらにパルス幅 $\mathrm{t}_{\mathrm{w}}$ と繰り返し周波数 $\mathrm{f}_{\mathrm{p}}$ を個 別に変化させ, これらのパラメータが部分放電特性に及ぼ 寸影響も検討した。試料には並列に結合コンデンサを接続 するとともに，低圧側に部分放電検出器を接続した。検出 器の出力電圧は差動プローブで計測することで, パルス電 圧に伴う充電電流およびノイズを低減しながら部分放電を 計測できるようにした。デジタルオシロスコープ内部では, 計測した信号をさらにデジタルハイパスフィルタ（遮断周 波数 $30 \mathrm{MHz}$ ）処理し，部分放電とノイズを分離した。試料 の印加電圧は高電圧プローブにて測定した。試験電圧は電 源のスライダックを手動で操作し約 $10 \sim 50 \mathrm{~V} / \mathrm{s}$ のスピード で昇，降圧した。部分放電開始電圧は，昇圧中に 1 発目の 部分放電がトリガされた時点の印加電圧とした。部分放電 消滅電圧は，降圧中に部分放電がトリガされなくなった時 点の印加電圧とした。

図 4 に幅の狭いパルス電圧を用いた絶縁物の課電寿命測 定回路を示す。課電寿命試験では市販のインバータの出力

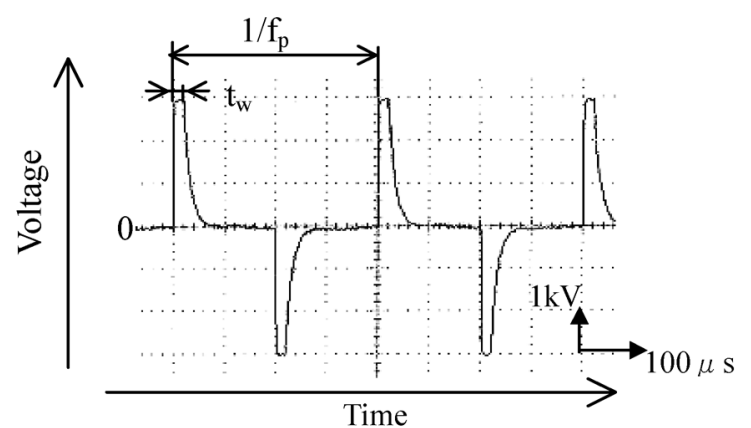

図 3 パルス電圧波形の例

Fig. 3. Example of pulse waveform.

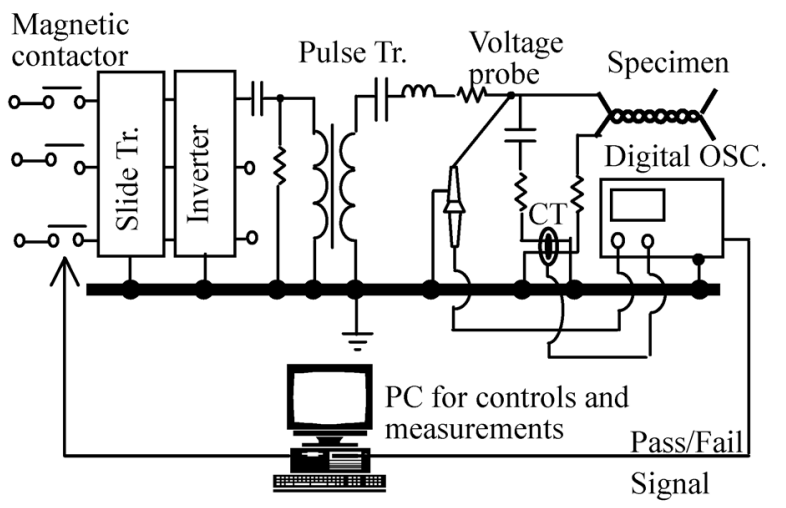

図 4 幅の狭いパルス電圧を用いた 課電寿命測定回路

Fig. 4. Electrical circuit for measuring time to failure applying pulse voltage with narrow pulse width.

に CRハイパスフィルタおよびパルストランスを接続し, 幅 の狭いパルス電圧を作成した。CRハイパスフィルタとパル ストランスの励磁アドミタンスで形成される合成フィルタ の遮断周波数は約 $200 \mathrm{kHz}$ であった。試料には並列に結合コ ンデンサを接続するとともに低圧側リード線を高周波 $\mathrm{CT}$ に互いに逆方向に貫通させることで, 充電電流およびノイ ズを低減しながら, 課電寿命試験中に発生する部分放電と, 試料が破壊した際の破壊電流を計測できるようにした。試 料を流れる電流が所定の值を上回るか, 印加電圧が所定の 值を下回った際に試料が破壊したと判定し, 制御用 PC にて インバータ電源の入力を遮断した。試料が破壊するまでの 時間は制御用 PC にて計測した。試料の印加電圧は高電圧プ ローブにて測定した。

\section{3. 実験結果}

〈3-1〉 部分放電計測回路特性 図 5 にパルス電圧を 印加して測定した部分放電の例を示す。一般にパルス電圧 下ではパルス電圧に伴う充電電流やノイズのため, 部分放 電の計測が困難である ${ }^{(6)}$ 。本試験では, 検出器 1,2 の電流 を差動プローブで測定することで, 検出器を流れる同極性 の充電電流およびノイズを打ち消し, 逆極性の部分放電を 

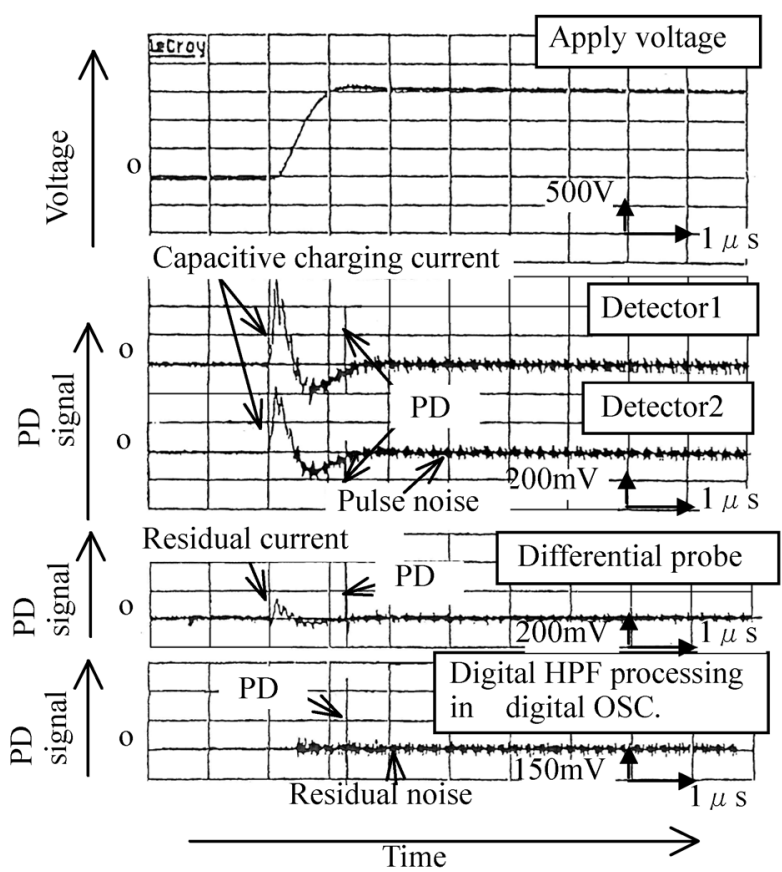

図 5 充電電流，ノイズを低減した部分放電計測

Fig. 5. Partial discharge (PD) measurements reducing capacitive current and noise.

測定している。また，測定した信号はデジタルハイパスフ イルタ処理することで残留充電電流やノイズを除去してい る。市販の電荷校正器で校正した結果, 最小検出可能部分 放電電荷量は，パルス電圧では $50 \mathrm{pC}$ ，正弦波電圧では $3 \mathrm{pC}$ であった。なお, 図 5 において, パルス電圧と充電電流が 立ち上がり始める時刻が僅かに異なっている。この原因に は, 電圧プローブ, フィルタ, デジタルオシロスコープ, デジタルフィルタなどの測定系における計測時間遅れの違 いが考えられる。

〈3.2〉 電圧立ち上がり時間と部分放電特性 図 6 に 電圧のパルス電圧と正弦波電圧を印加したときの部分放電 特性を示す。マイカ，ポリイミド，DGC，エナメル+DGC について試験した。各試料のプロット数は試験した試料数 を示す。試料毎にばらついているが，各試料で見るといず れの試料でもパルス電圧と正弦波電圧の部分放電開始電 圧, 消滅電圧, 部分放電開始電圧における最大放電電荷量 はほぼ一致している。このことから, 電圧立ち上がり時間 が部分放電特性, 特に部分放電開始電圧, 消滅電圧, 開始 電圧における部分放電電荷量に及ぼす影響は小さいと考え られる。

図 7 に, パルス電圧を印加した際の部分放電発生位相を 示す。パルス電圧がピークに達しても部分放電は直ちには 発生せず, 数 $\mu \mathrm{s}$ 遅れて発生している。また, 部分放電は不 規則に発生している。同様の現象は他にも報告されており, パルス電圧に特有の現象と考えられる(6)。パルス電圧ではこ のように電圧を印加してから時間遅れを伴って部分放電が 発生することから，パルス幅が部分放電特性に影響する可 能性が考えられる。

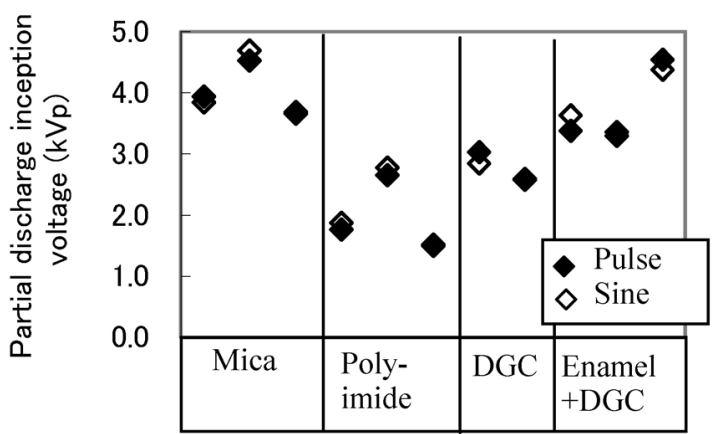

(a) Inception voltage

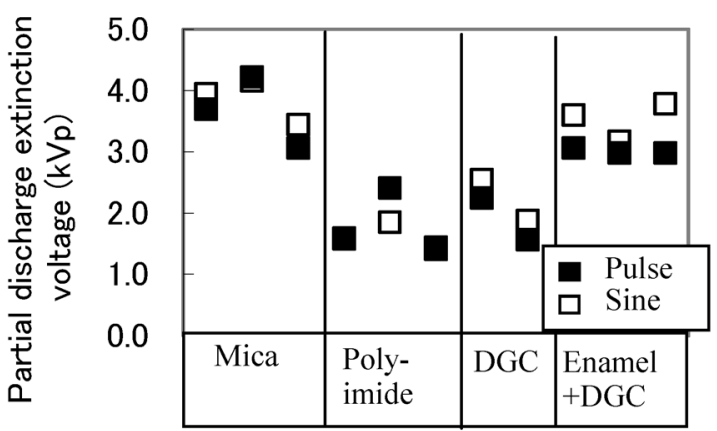

(b) Extinction voltage

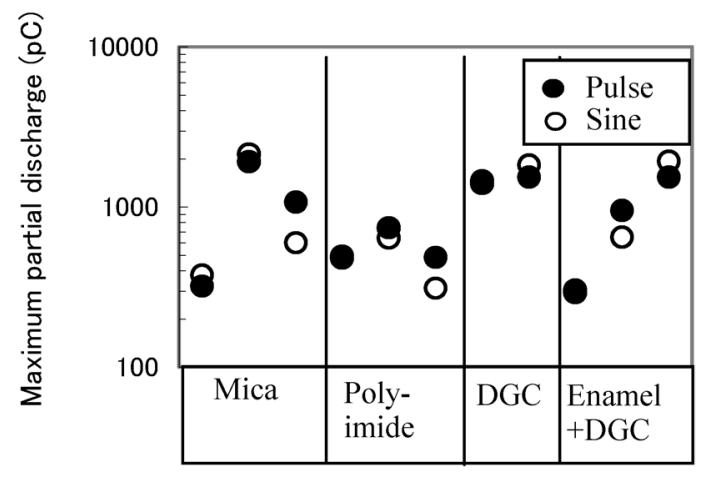

(c) Maximum partial discharge at inception voltage

Pulse (rise time: $1 \mu \mathrm{s}$, width: $100 \mu \mathrm{s}$, frequency:500Hz) Sine (frequency: $50 \mathrm{~Hz}$ )

図 6 電圧の立ち上がり時間を変化させたときの部分放電 開始電圧, 消滅電圧, 放電開始電圧 における最大放電電荷量

Fig. 6. Partial discharge inception voltage, extinction voltage and maximum partial discharge at inception voltage changing rise time of voltage.

\section{〈3.3〉 パルス幅, 繰り返し周波数と部分放電特性}

図 8 に電圧のパルス幅と繰り返し周波数を変化させたと きの部分放電特性を示す。パルス幅を狭くすると部分放電 開始電圧が増加する。また, 部分放電開始電圧における最 大放電電荷量も増加する。ただし, 繰り返し周波数を高く すると，これらの值はパルス幅を狭くしても増加しなくな る。一方, 部分放電消滅電圧はパルス幅や繰り返し周波数 を変化させても変化しない。

図 9 に一定の大きさのパルス電圧を印加して測定した部 

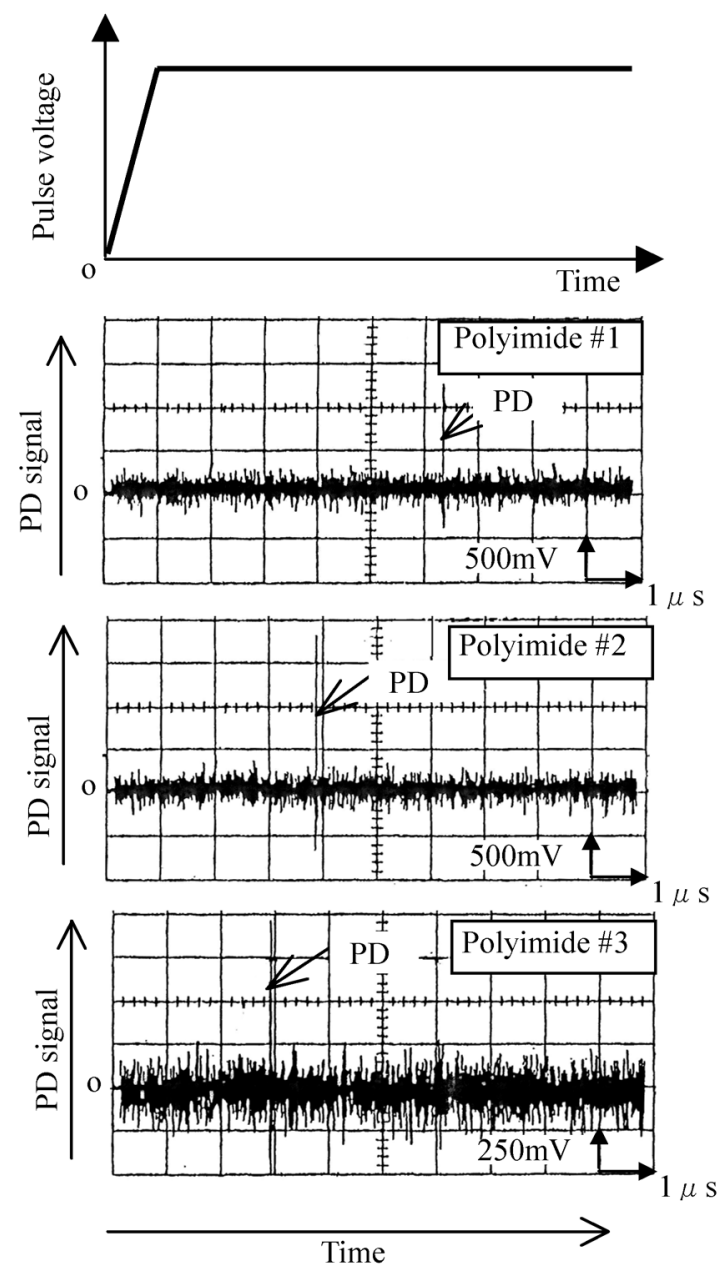

図 7 パルス電圧下の部分放電発生位相

（試料：ポリイミド）

Fig. 7. Phase time of partial discharge (PD) generated by pulse voltage (sample: polyimide).

分放電発生頻度を示す。正弦波電圧における部分放電開始 電圧付近の電圧を印加して試験した。部分放電発生頻度は 1 電圧サイクルあたりの発生数（Pulse Per Cycle）に換算し表 示した。パルス幅を狭くすると部分放電発生頻度が低下寸 る。ただし，印加電圧を高くすると部分放電発生頻度の絶 対值が増加するとともに，パルス幅に対する部分放電発生 頻度の傾きが小さくなる。今回，図 8 の部分放電計測では 印加電圧を昇圧しながら部分放電開始電圧を計測したが, 幅の狭いパルス電圧では部分放電発生頻度が低いため，部 分放電が計測される前に印加電圧が昇圧され, 結果的に部 分放電開始電圧が高くなった可能性が示唆される。

なお, 図 8 と図 6 の Polyimide では部分放電開始電圧, 消 滅電圧，最大放電電荷量が異なっている。この原因につい ては不明であるが，試料の部分放電特性のばらつきが可能 性の 1 つとして考えられる。

図 10 に紫外線を照射しながら電圧のパルス幅と繰り返し 周波数を変化させたときの部分放電特性を示す。紫外線を 照射した場合，パルス幅，繰り返し周波数を変化させても 部分放電開始電圧, 消滅電圧, 放電開始時の最大放電電荷

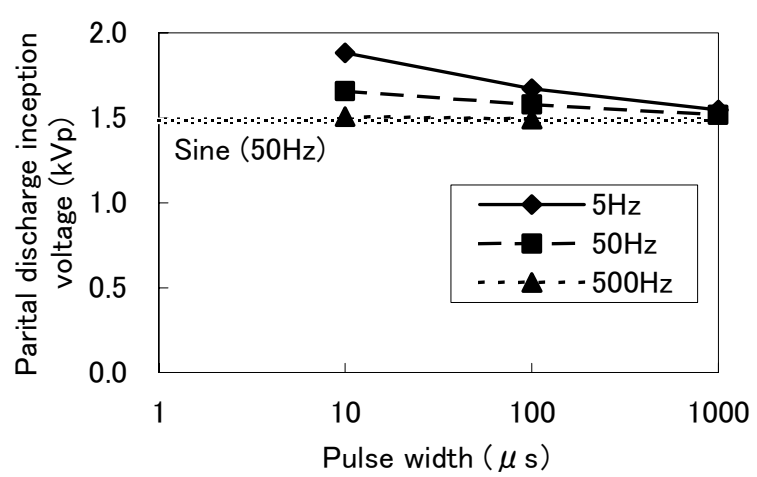

(a) Inception voltage

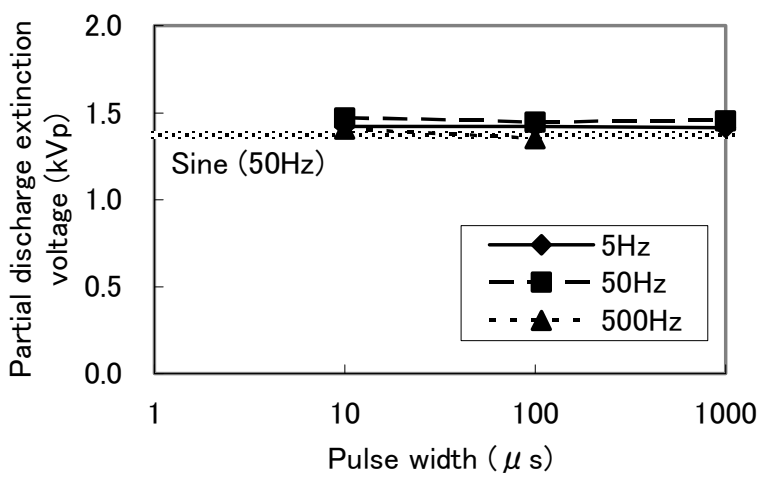

(b) Extinction voltage

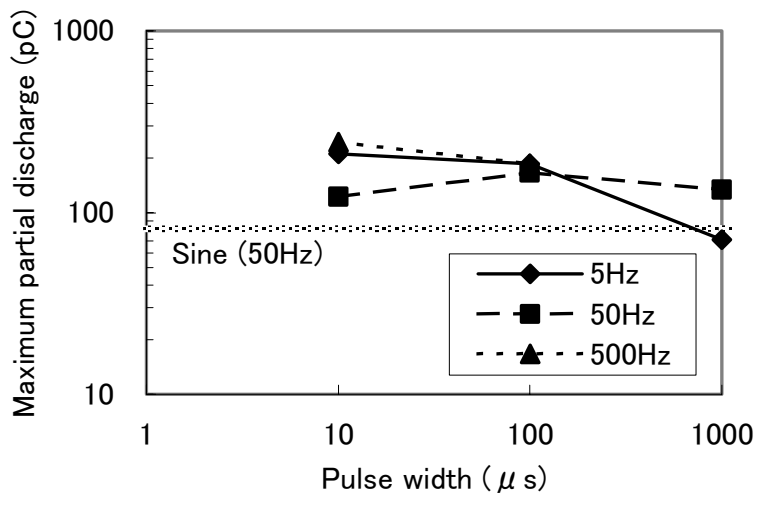

(c) Maximum partial discharge at inception voltage

図 8 パルス幅と繰り返し周波数を変化させたときの 部分放電開始電圧，消滅電圧，放電開始電圧 における最大放電電荷量（試料：ポリイミド）

Fig. 8. Partial discharge inception voltage, extinction voltage and maximum partial discharge at inception voltage changing width and frequency of pulse voltage compared with sine voltage (sample: polyimide).

量は変化しなかった。紫外線を照射した場合, 試料周囲で 初期電子が安定的に生成されることが考えられる。紫外線 を照射した場合にはパルス幅を狭くしても部分放電開始電 圧が増加しなかったことから，パルス幅を狭くすると部分 放電開始電圧が増加し部分放電発生頻度が低下寸る原因に は, 初期電子の発生確率が関係している可能性が示唆され る。

〈3·4〉 印加電圧の大きさと部分放電特性 図 11 に印 加電圧の大きさを変化させたときの最大放電電荷量を示 


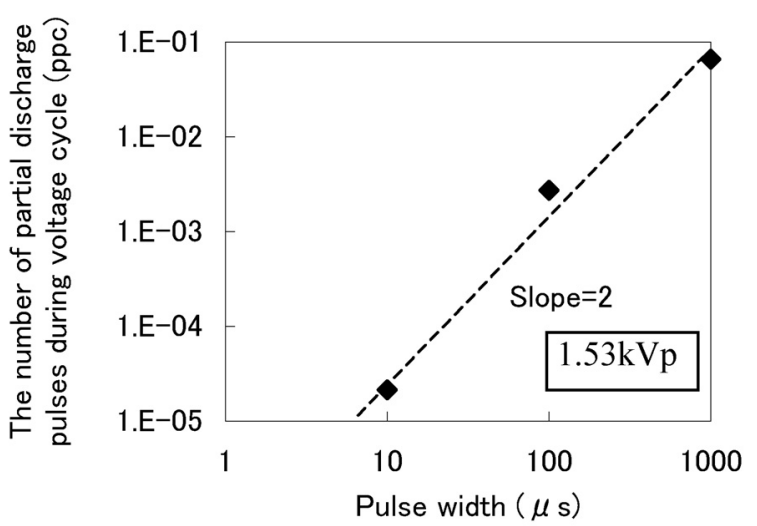

(a) Around partial discharge inception voltage of sine

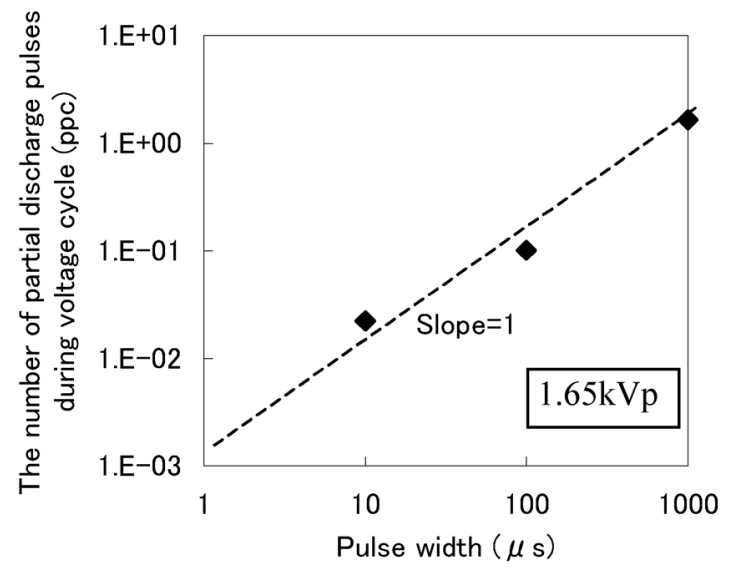

(b) Over partial discharge inception voltage of sine

図 9 正弦波電圧の部分放電開始電圧付近の電圧で パルス幅を変化させた際の部分放電発生頻度

(試料：ポリイミド，周波数 : $50 \mathrm{~Hz}$ )

Fig. 9. The number of partial discharge changing pulse width of voltage around partial discharge inception voltage of sine (sample: polyimide, frequency:50Hz).

す。正弦波電圧を印加した場合, 部分放電開始電圧以上の 電圧における最大放電電荷量はほぼ一定となっている。一 方，パルス電圧を印加した場合，印加電圧とともに最大放 電電荷量が増加している。ところで，ピーク電圧が等しい 場合，パルス電圧と正弦波電圧の課電寿命がほぼ一致する ことが報告されている(5)。ただし，その原因についてはまだ 十分検討がされていない。今後，今回のような部分放電特 性も含めてパルス電圧下の課電寿命特性を検討する必要が あると考えられる。

〈3·5〉 パルス幅, 電圧の大きさと課電寿命特性以 上の結果，パルス電圧ではパルス幅と印加電圧の大きさが 課電寿命特性に大きく影響する可能性が示唆された。そこ で，次にパルス電圧のパルス幅と電圧の大きさを変化させ て課電寿命特性を測定した。試験にはツイストペアエナメ ル電線と図 4 の回路を使用した。

図 12 にパルス幅と課電電圧の大きさを変化させたときの 課電寿命測定結果を示す。いずれのパルス幅でも，電圧が 高くなるとともに寿命は短くなる。高電圧側ではパルス幅

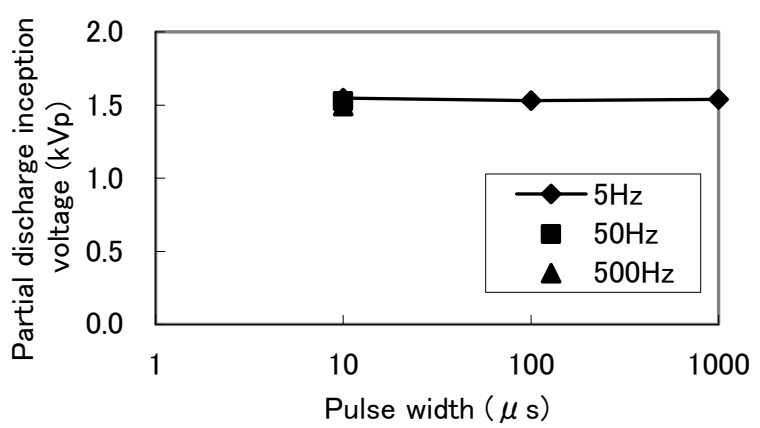

(a) Inception voltage

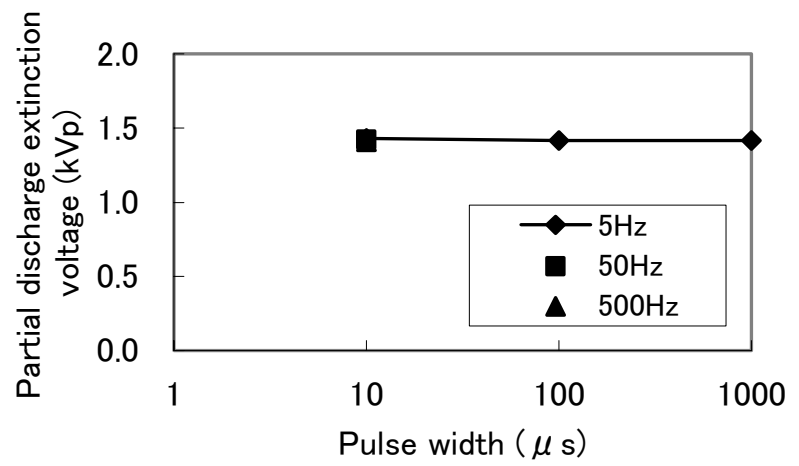

(b) Extinction voltage

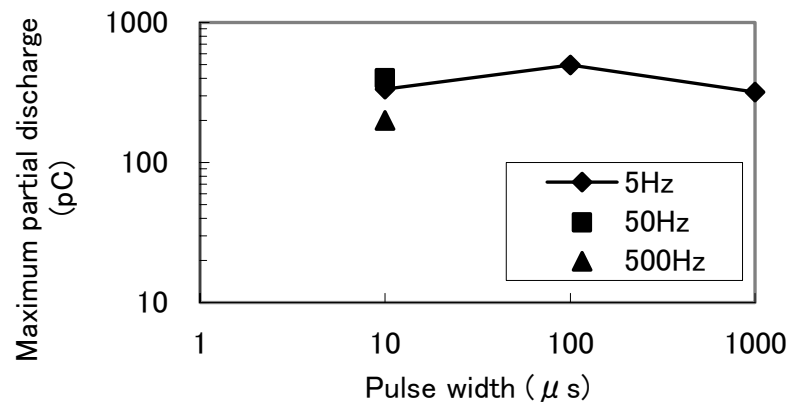

(c) Maximum partial discharge at inception voltage

図 10 紫外線を照射してパルス幅と繰り返し周波数を 変化させたときの部分放電開始電圧，消滅電圧， 放電開始電圧における最大放電電荷量

（試料：ポリイミド）

Fig. 8. Partial discharge inception voltage, extinction voltage and maximum partial discharge at inception voltage changing width and frequency of pulse voltage compared with sine voltage (sample: polyimide).

$1 \mu \mathrm{s}, 100 \mu \mathrm{s}$ の課電寿命はほぼ一致している。しかし, 低電 圧側ではパルス幅 $1 \mu \mathrm{s}$ の課電寿命はパルス幅 $100 \mu \mathrm{s}$ の課電寿 命より長くなる。また, 課電寿命曲線が水平になり寿命が ほぼ無限大になる電圧も，パルス幅が狭くなるほど高くな る。このことから, 低電圧領域, 特に部分放電開始電圧付 近の電圧領域では，パルス幅と印加電圧の大きさが巻線間 絶縁の部分放電劣化特性や課電寿命特性に大きく影響する ことが示された。

図 13 にパルス幅 $1 \mu \mathrm{s}$ 付近における部分放電開始電圧の結 果を示す。図 13 では正弦波電圧における部分放電開始電圧 


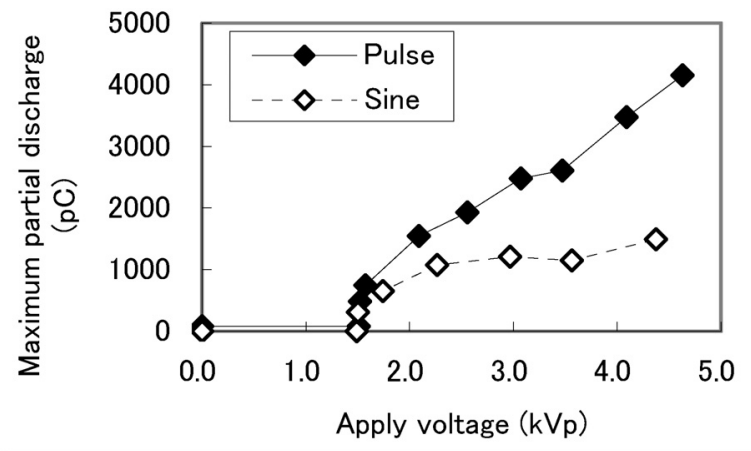

Pulse (rise time: $1 \mu \mathrm{s}$, width: $100 \mu \mathrm{s}$, frequency:500Hz) Sine (frequency: $50 \mathrm{~Hz}$ )

図 11 印加電圧を変化させたときの最大放電電荷量 (試料：ポリイミド)

Fig. 11. Maximum partial discharge increasing apply voltage (sample: polyimide).

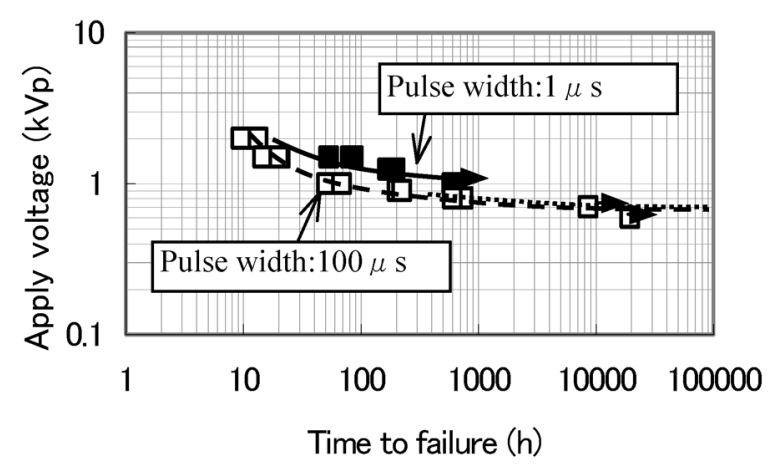

図 12 パルス幅と印加電圧を変化させたときの課電寿命特性 (試料 : ポリエステルイミド／ポリアミドイミド, 周波数 : $500 \mathrm{~Hz}$ )

Fig. 12. Lifetime characteristics changing pulse width (sample: polyester-imide/polyamide-imide, frequency: $500 \mathrm{~Hz})$.

を 1.0 としてパルス電圧の部分放電開始電圧を表した。な お，図 13 には図 8 の結果も併記した。パルス幅が狭くなる とともに部分放電開始電圧が高くなる。特にパルス幅が $1 \mu \mathrm{s}$ 程度になると, 繰り返し周波数を高くしても部分放電開始 電圧はほとんど低下しなくなる。一般に課電寿命特性では 部分放電開始電圧以下では寿命が著しく長くなり，ほぼ無 限大になると考えられている(7)(8)。したがって，図 12 にお いて, パルス幅 $1 \mu \mathrm{s}$ の課電寿命曲線が水平になり寿命がほぼ 無限大になる電圧がパルス幅 $100 \mu \mathrm{s}$ よりも高くなった原因 には, パルス幅の減少に伴い部分放電開始電圧が増加した ことが考えられる。

図 14 にサージ電圧をモータに印加した際の巻線間電圧の 測定結果を示す。対地間サージ電圧が U1〜U4 へとモータ巻 線を伝播する際の伝播遅れに伴い, モータ巻線間にパルス 電圧が発生している。この電圧のパルス幅は約 $1 \mu \mathrm{s}$ である。

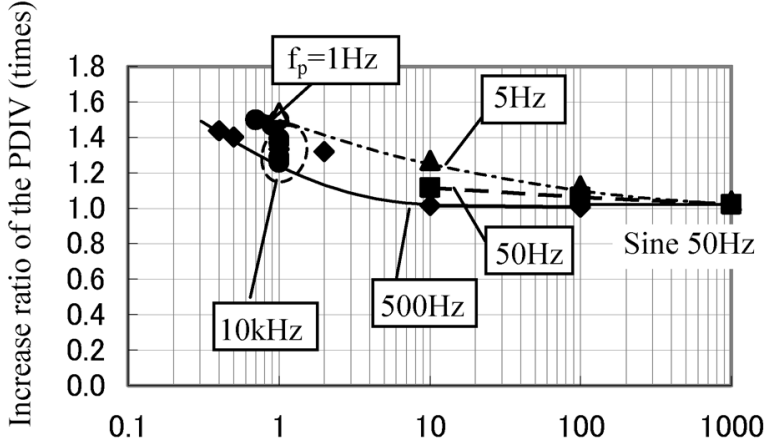

Pulse width of the apply voltage ( $\mu \mathrm{s})$

図 13 パルス幅を変化させたときの部分放電開始電圧 (fp：パルス繰り返し周波数)

Fig. 13. Increase of the partial discharge inception voltage (PDIV) decreasing the pulse width compared with sine $50 \mathrm{~Hz}$ voltage (fp: pulse frequency).

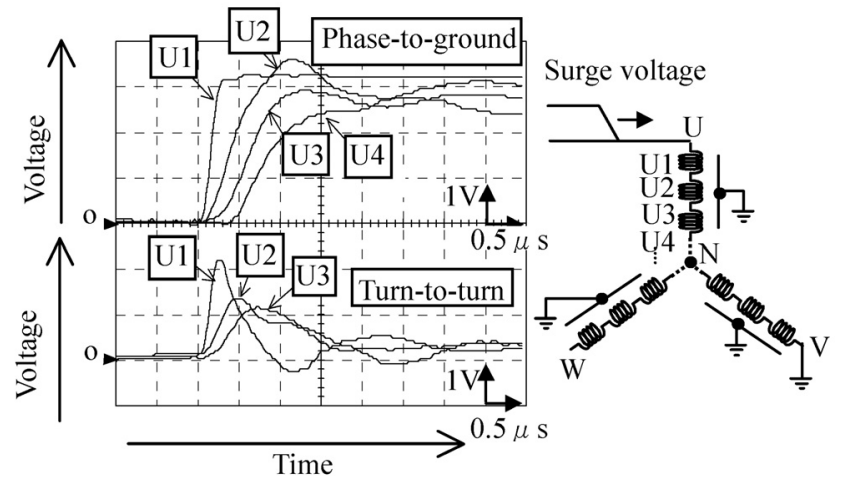

図 14 サージ電圧を印加したときの モータ巻線間電圧

Fig. 14. Turn-to-turn voltage of motor applied surge voltage.

図 12 , 図 13 ではパルス幅が $1 \mu \mathrm{s}$ 以下になると部分放電特性, 課電寿命特性が大きく変化することから，インバータ駆動 モータではモータ巻線間に実際に発生する電圧のパルス幅 を測定するとともに，幅の狭いパルス電圧に対する絶縁材 料の特性を評価し, モータ絶縁設計をしなければならない ことが示された。

\section{4. 考察}

以上の検討の結果，下記の知見が得られた。

（1）印加電圧のパルス幅を狭くすると部分放電開始電 圧は増加し, 部分放電発生頻度は低下寸る。また, 課電寿 命は長くなる。

（2）電圧の繰り返し周波数を高くするか, 紫外線を照射 すると, 部分放電開始電圧の増加は少なくなる。

( 3 ) 部分放電開始電圧以上ではパルス電圧の大きさと ともに部分放電電荷量が大きくなる。

これらの原因の 1 つには, 火花放電遅れ, 特に統計遅れ が考えられる。図 15 にパルス電圧下における空気の火花放 電遅れの概念図を示す ${ }^{(9)}$ 。一般に, 高電圧を印加した際に空 


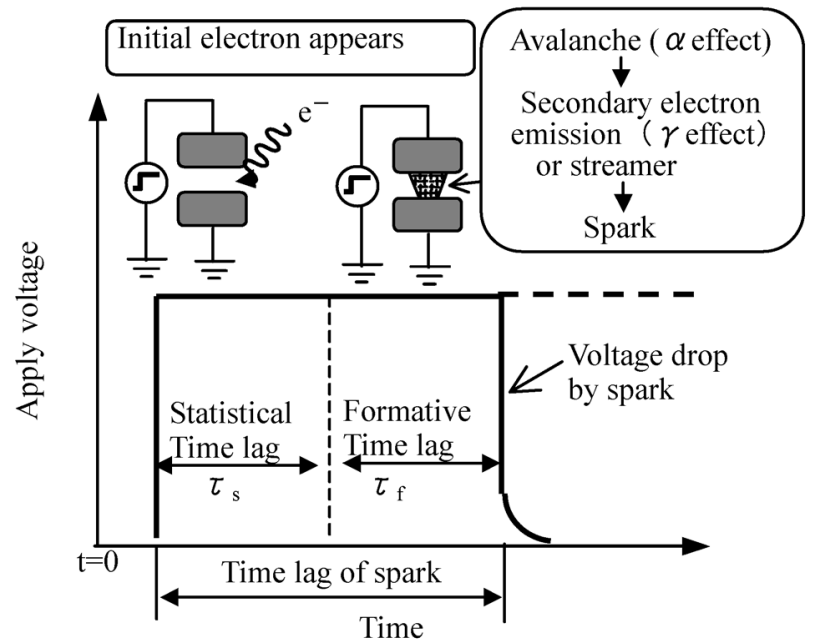

図 15 パルス電圧下の空気の火花遅れ（概念図） ${ }^{(10)}$

Fig. 15. Time lag of spark applying pulse voltage (Schematic diagram)

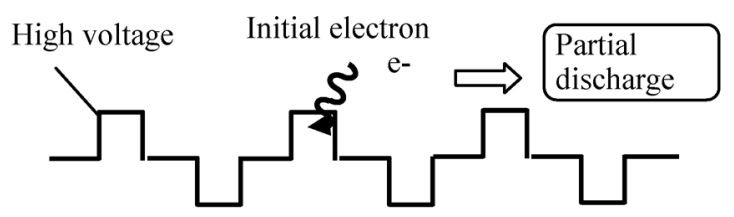

(a) Repetitive frequency: high (ex. 500Hz)

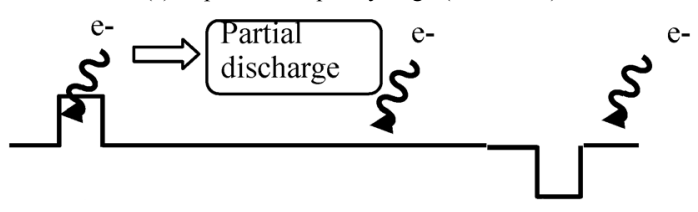

(b) Repetitive frequency: low (ex. $5 \mathrm{~Hz})$, UV irradiation

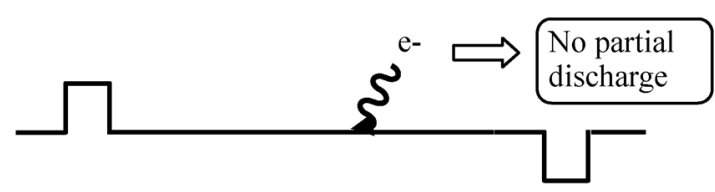

(c) Repetitive frequency: low (ex. $5 \mathrm{~Hz}$ ), UV irradiation: No

図 16 繰り返し周波数および紫外線照射が 部分放電特性に及ぼす影響の検討

(概略図)

Fig. 16. Consideration on effects of repetitive frequency and UV irradiation for partial discharge characteristics (Schematic diagram).

気が火花放電に至るには, 初期電子が出現するまでの統計 遅れ時間と, 初期電子が加速されて火花放電が完成するま での形成遅れ時間の和で表される火花遅れ時間が必要であ る。このため, 印加電圧のパルス幅が狭くなりパルス幅が 火花遅れ時間と同等以下になると，火花放電が完成する前 に高電圧が取り除かれるため火花放電に至らなくなる。し たがって，今回，パルス幅を狭くした際に部分放電発生頻 度が低下, 部分放電開始電圧が増加し, 課電寿命が長くな った原因には，パルス幅が火花放電遅れに比べて短くなっ

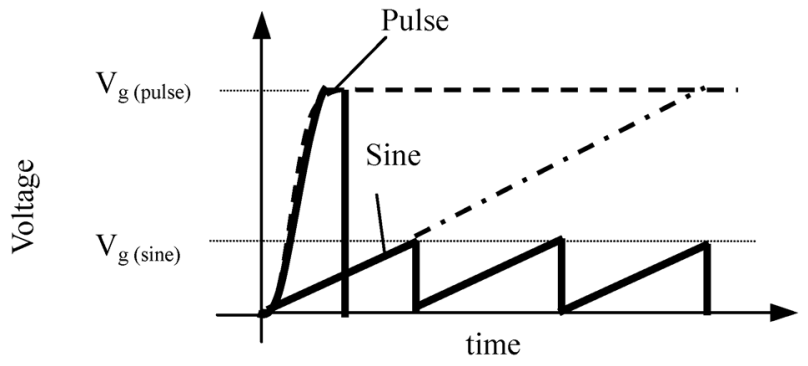

(a) Voltage between air gap

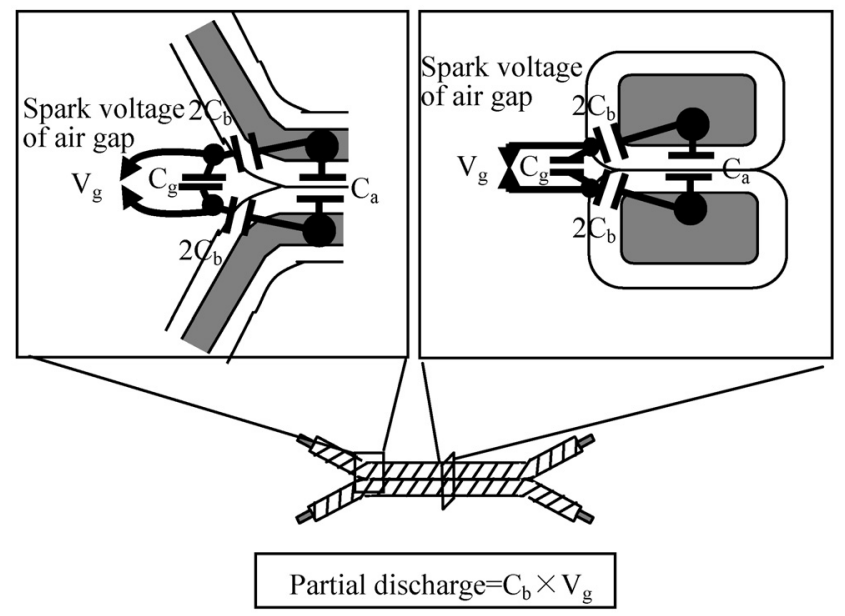

(b) Partial discharge of air gap

図 17 部分放電開始電圧以上のパルス電圧と 正弦波電圧を印加した際に空気に加わる

電圧 $\mathrm{V}_{\mathrm{g}}$ と部分放電電荷量 $\mathrm{Q}$ の関係

Fig. 17. Relationship between voltage of air gap and partial discharge (PD) applying pulse and sine voltage over partial discharge inception voltage.

たことが考えられる。ただし, 図 9 では部分放電発生頻度 が少ないもののパルス幅の狭い電圧でも部分放電が発生し ている。電圧のパルス幅が形成遅れ時間より短い場合には 火花放電が発生しなくなることから, 今回試験したパルス 幅は形成時間遅れ以上であり, 統計遅れ時間十形成遅れ時 間以下であったと考えられる。すなわち，今回の実験結果 では火花放電遅れの中でも特に初期電子が出現するまでの 統計遅れが時間の影響が大きかったと考えられる。

以上のことを踏まえ, 繰り返し周波数と紫外線照射が部 分放電特性に与える影響を検討した結果を図 16 に示す。繰 り返し周波数を高くした場合, 初期電子が出現した時刻に 高電圧が発生している確率が高くなり, 火花放電に至る確 率が高くなる。また, 紫外線を照射した場合には, 初期電 子が安定して供給され, パルス電圧が印加されている間に 初期電子が発生し火花放電に至る確率が高くなる。この結 果, 繰り返し周波数を高くするか, 柴外線を照射した場合 には，パルス幅を狭くしても部分放電開始電圧が増加しな かったと考えられる。

一方, 部分放電開始電圧以上で最大放電電荷量が印加電 圧とともに増加した原因の 1 つにも, 火花放電遅れが考え 
Expansion of partial discharge

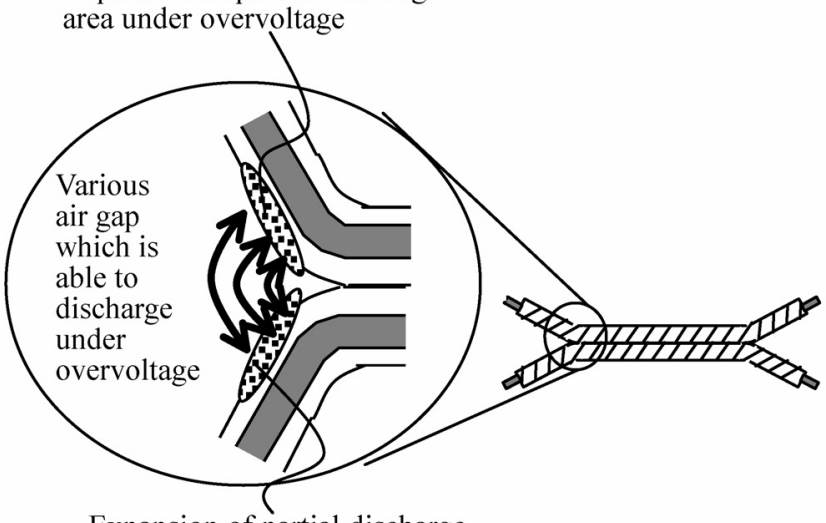

Expansion of partial discharge area under overvoltage 広がりの検討

Fig. 18. Consideration on partial discharge expansion at the edge of specimen when occurring overvoltage by time lag of spark.

られる。図 17 に, 部分放電開始電圧以上のパルス電圧と正 弦波電圧を印加した際に空気に加わる電圧 $V_{\mathrm{g}}$ と部分放電電 荷量 Q の関係を示す。パルス電圧では印加電圧を大きくし ても, 火花放電遅れのため瞬間的に正弦波の火花放電電圧 $\mathrm{V}_{\mathrm{g}(\text { (sine) }}$ 以上の高電圧（過電圧） $\mathrm{V}_{\mathrm{g}(\text { pulse })}$ が印加され火花放電が 発生することが考えられる。ところで, 部分放電電荷量 $\mathrm{Q}$ は空気の火花放電電圧 $\mathrm{V}_{\mathrm{g}}$ と空気に直列な静電容量 $\mathrm{C}_{\mathrm{b}}$ との 積で決まる(10)。したがって，パルス電圧では印加電圧を高 くするとともに部分放電電荷量が増加したと考えられる。

ただし，今回試験に使用した試料では，図 18 に示すよう に，試料両端部においてエアギャップが広がっており，部 分放電が発生するエアギャップや放電面積に制限が無い。 このため, 過電圧に伴い部分放電発生箇所や面積が広がり 部分放電電荷量が増えた可能性も考えられる。

さらに，以上の考察では個々のパルス電圧で部分放電現 象が独立して発生すると仮定して考察した。しかし, 実際 には複数のパルス電圧が繰り返し絶縁物に印加されてい る。このような場合, 先に印加された電圧による絶縁物へ の電荷蓄積が次のパルス電圧の部分放電特性に影響を及ぼ 寸可能性も十分考えられる(11)(12)。今回の実験では繰り返し パルス電圧の周期（周波数）を一定にし，パルス幅を変化 させたためパルス休止期閒が異なっている。繰り返し周波 数が低い領域ではパルス幅に比べてパルス休止期間が長い ため休止期間の影響は少ないと考えられるが，繰り返し周 波数が高い領域では休止期間の影響は無視できない。今後, 繰り返しインパルス電圧における部分放電特性を検討する 際にはパルス休止期間を一定にし, 電荷の蓄積や拡散の影 響も検討する必要があると考えられる。

以上のようにパルス電圧下における部分放電特性, 課電 劣化寿命特性は複雑な現象によって支配されている可能性 があるため, 今後, さらにこれらの現象を区別できる試料

や試験方法を考案し，パルス電圧下における部分放電特性, 劣化特性を検討する必要があると考える。

\section{5. まとめ}

インバータ駆動モータの巻線間絶縁特性を検討するた め, パルス電圧を印加したときの絶縁物の部分放電特性お よび課電寿命特性を検討した。この結果, モータ巻線間に 発生する幅の狭いパルス電圧では部分放電開始電圧が増加 する。また, 部分放電発生頻度が低下し, 課電寿命が長く なることが明らかになった。インバータ駆動モータではモ 一タ巻線間に実際に発生する電圧のパルス幅を測定すると ともに, 幅の狭いパルス電圧に対する絶縁材料の特性を評 価し, モータ絶縁設計をしなければならないことが示され た。

(平成 19 年 9 月 27 日受付, 平成 19 年 12 月 10 日再受付)

\section{文献}

(1)「インバータサージの絶縁システムへの影響」, 電気学会技術報告, No.739, pp.6-11 (1999)

(2) K. J. Cornick and T. R. Thompson : "Steep-front switching voltage transients and their distribution in motor windings Part 2: Distribution of steep-front switching voltage transients in motor windings", IEE Proc., Vol.129, Pt. B, No.2, pp.56-63 (1982)

(3) Gambica/Rema : "Variable Speed Drives and Motors: Motor Insulation Voltage Stresses under PWM Inverter Operation”, Technical Report, No.1, pp.2-6 (2001)

(4) K. Obata, K. Fukushi, and R. Takeuchi : "Turn to Turn Insulation of Motor Fed by Inverter", Proceeding of the 34th Symposium on Electrical and Electronic Insulating Materials and Applications in Systems, pp.165-168 (2002) (in Japanese)

尾畑功治・福士慶滋・武内良三:「インバータ駆動モータの層間絶縁」, 第 34 回電気電子絶縁材料シンポジウム, pp.165-168 (2002)

(5) K. Obata, K. Fukushi, and R. Takeuchi : "Lifetime Characteristics of Electrical Insulation in Motor Fed by Inverter", IEEJ Trans. FM, Vol.125, No.3, pp.261-267 (2005-3) (in Japanese)

尾畑功治・福士慶滋・武内良三 :「インバータサージ電圧下の課電寿 命特性」, 電学論 A, 125, 3, pp.261-267 (2005-3)

(6) 森 興次・井上良之:「パルス電圧による部分放電発生特性」, 電気 学会誘電絶縁材料研資, DEI-93-120, Vol.3, No.4, pp.9-18 (1993)

( 7 ) M. Kaufhold, G. Borner, M. Eberhardt, and J. Speck : "Failure Mechanism of the Interturn Insulation of Low Voltage Electric Machines Fed by Pulse-Controlled Inverters", IEEE Electrical Insulation Magazine, Vol.12, No.5, pp.9-16 (1996)

(8) Gambica/Rema : "Variable Speed Drives and Motors: Motor Insulation Voltage Stresses under PWM Inverter Operation”, Technical Report, No.1, p.10 (2001)

(9) 電気学会編 : 放電ハンドブック (上), p.132 (1998)

(10) F. H. Kreuger : Partial Discharge Detection in High-Voltage Equipment, p.29, Butterwoths (1989)

(11) K. Kimura, S. Itaya, S. Ushirone, M. Hitkita, and W. Bito : "Discharge Condition and Surface charge Distribution under Repetitive Bipolar Impulses", Proc. of the $7^{\text {th }}$ International Conference on Properties and Applications of Dielectric Materials, Vol.3, pp. 1061-1064, Nagoya (2003-6)

(12) K. Inuzuka, M. Morikawa, N. Hayakawa, T. Hirose, M. Hamaguchi, and H. Okubo: "Partial Discharge Inception Characteristics of Nanocomposite Enamel Wire for Inverter-Fed Motor", 2006 National Convention Record IEE Japan, p.60 (2006) (in Japanese)

犬塚健太・森川真人・早川直樹・広瀬達也・浜口昌弘・大久保仁 :「イ ンバータ駆動モータ用ナノ複合エナメル線の部分放電開始特性, 平 成 18 年電気学会全国大会, p.60(2006) 


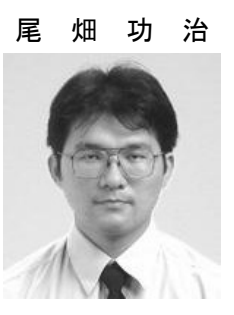

（正員） 1972 年 9 月 6 日生。1997 年 3 月名古 屋大学大学院工学研究科電気工学専攻修士課 程修了。同年 4 月（株）日立製作所に入社。日 立研究所にて回転電機絶縁の研究に従事。2007 年電気学会論文賞受賞。

武内良三

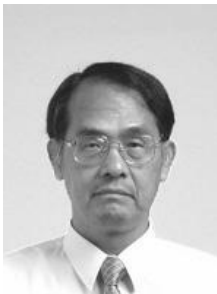

下 薗 忠 弘

（非会員） 1973 年 10 月 20 日生。 2000 年 3 月 東京大学大学院工学系研究科修士課程修了。同 年 4 月（株）日立製作所入社。 2002 年 4 月（株） 日立産機システム設立に伴い転属。誘導電動機 及び DCブラシレスモータの設計・開発に従事。

菊 池 英 行 (非会員) 1966 年 2 月 16 日生まれ。1988 年 3

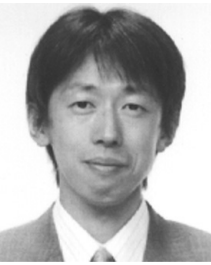
月東京電機大学電子工学科卒業。同年 4 月日立 電線（株）入社。2002 年 8 月より日立マグネッ トワイヤ (株) 設立に伴い出向。1989 年より巻 線の開発業務に従事。1996 年より樹脂合成及び ナノコンポジット材料の研究開発を推進。2001 年電気学会優秀論文発表賞受賞。 